\title{
Georgius Frommius (1605-1651) and Danish Astronomy in the Post-Tychonian Era
}

\author{
Helge Kragh \\ Niels Bohr Institute, \\ Copenhagen University \\ Blegdamsvej 17, \\ Copenhagen 2100, Denmark \\ E-mail: helge.kragh@nbi.ku.dk
}

\begin{abstract}
Danish astronomy in the first half of the seventeenth century reflected the enduring legacy of Tycho Brahe and was dominated by his former assistant Longomontanus. This paper focuses on his successor as professor of astronomy, Jørgen From (1605-1651) or Georgius Frommius in the Latin version, who was also the second director of the Round Tower observatory in Copenhagen. Before becoming a professor, Frommius travelled to the Netherlands and other countries. The letters from his journey cast light on the training of a young astronomer at the time. He most likely was the first Dane to observe the heavens with a telescope. In the 1640s, he got involved in a controversy with the French astronomer and astrologist Jean Morin, and he later contributed to Pierre Gassendi's pioneering biography of Tycho Brahe. Although Frommius died at the age of 46 , his brief career as professor and astronomer is of interest to national as well as international history of science.
\end{abstract}

Keywords: astronomy in Denmark, early telescopes, Georgius Frommius (Jørgen From), Jean Morin, Longomontanus, Round Tower observatory, study travels, Tycho Brahe 


\section{Introduction}

As seen from an international perspective, Danish astronomy in the early modern period is characterized primarily by Tycho Brahe and secondarily by Ole Rømer. While much has been written about these two figures in the reformation of astronomy, the intervening period of more than seventy years has attracted much less attention among historians of science. Longomontanus is well known, but he is not the only Danish astronomer of interest in the period from about 1610 to 1670 . The present essay offers a general introduction to the subject with special emphasis on Longomontanus's little known successor as professor of astronomy, Georgius Frommius or Jørgen From. By looking at the brief and relatively undistinguished career of Frommius, I intend to provide a picture of Danish astronomy in the mid-seventeenth century that is more contextual and fine-grained than the one usually presented. It turns out that at the time Frommius was not the anonymous figure he is today. In fact, he was fairly well known and interacted with influential natural philosophers such as Hortensius in the Netherlands and Morin and Gassendi in France.

This was also the period in which the Round Tower, the second oldest university observatory in the world (and the oldest still existing), was built in Copenhagen. By focusing on Frommius, one obtains new information about the observatory and the astronomers' use of and attitude to the telescope, which at the time had still not become a standard instrument in observational astronomy. I also use the occasion to correct some mistakes in the national and international literature. ${ }^{1}$

\section{Astronomy between Tycho and Rømer}

Tycho Brahe went into exile from the island of Hven in 1597 and died in Prague five years later. In spite of being exiled and having fallen out of favour with the king, Christian IV, astronomy at Copenhagen University remained strongly influenced by Tycho's ideas for more than half a century (Moesgaard, 1972). An important reason for the enduring Tychonic dominance was the appointment in 1607 of Christian Sørensen to a professorship in mathematics (mathematum infiriorum), which he changed in 1621 to a new chair in astronomy (mathematum superiorum).

\footnotetext{
Most of the secondary sources are written in Danish. For this reason I quote them sparingly and only when no other sources are available. I have taken care to include as many relevant sources as possible in English and other more commonly known languages.
} 


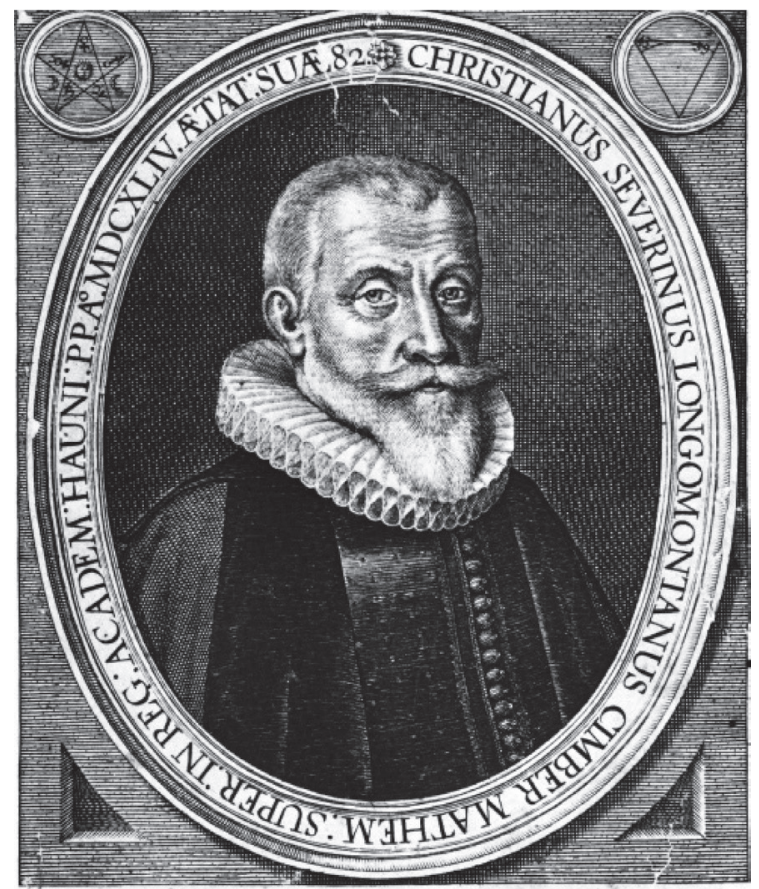

TiPrinceps menfor Sicufus SPHER MMatz CYLINDRUM Apponi Bus to fecerat arte suo: 0 (o) $\mathcal{S}_{i c}$ Christiane tuo Longomontane Sepulchro CIRCULVS inforior gaudet, et ASTRA simul. Scania Jychonem genuit, te Cimbrica tellus; Oucis, spretâ jnitiâ, fama perennis erit.

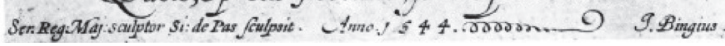

Figure 1. Longomontanus (1562-1647).

Plate by Simon de Pas, 1644 .

Sørensen, who is better known under his Latinized name Longomontanus or sometimes Christianus Severinus, held the chair until his death in 1647 (Fig. 1). As one of Tycho's most trusted assistants, first on Hven in 1589-1597 and then in Prague in 1600, where he stayed together with Johannes Kepler, he held the astronomical reform programme of his master in the highest respect (Voelkel, 2000; Christianson, 2000, pp. 313-319). Indeed, he saw it as his scientific as well as patriotic duty to defend Tycho's system and further improve it.

However, Longomontanus went closer to the Copernican system than Tycho had done by accepting that the Earth performed a daily rotation rather than the heavens rotated round the immobile Earth. On the other hand, he continued to reject the decisive element in the Copernican theory, namely the idea that the Earth was a planet travelling in a circular orbit around the Sun. Longomontanus was not the only of Tycho's former assistants who accepted the "Tycho-Copernican" notion of a rotating Earth. Norwegian-born Cort Aslaksen, who had worked with Tycho in 1590-1593, did the same in De natura caeli triplicius, published in 1597. The work was in the tradition of so-called Mosaic physics aiming at reconciling the Old Testament and scientific astronomy, of which he was an ardent advocate (Moesgaard, 1977; Blair, 2000). Like Longomontanus, Aslaksen became a professor at Copenhagen University, first in pedagogy and Greek and since 1607 in theology. 
Longomontanus's main work Astronomia Danica was published in Amsterdam in 1622 and subsequently in new editions of 1633 and 1640 (Moesgaard, 1972, pp. 126-133). Often repeated claims of an edition of 1660 cannot be verified and are probably misleading (Hede Jensen, 1985). Based on Tychonian principles and aimed as an alternative to Copernican as well as Ptolemaic astronomy, the main part of the book was a careful comparison of observations and calculations derived from the three world systems. Cosmologically he argued in favour of the Tychonic system, whereas he ruled out the annual motion of the Earth that characterized the rivalling Copernican system. Moreover, as the first Nordic astronomer he referred to Kepler's ideas about elliptical planetary orbits, if only to reject them as artificial and unphysical. For Longomontanus, as for Tycho, the ancient doctrine of uniform circular motion was not up for discussion. Astronomia Danica was well received and widely used, both in Denmark and abroad. For example, it was used at the Royal Greenwich Observatory in England, and notable owners of the book included Christopher Wren, Christiaan Huygens and Ole Rømer (Hede Jensen, 1985).

In spite of his sympathy for some of the features of Copernican astronomy, Longomontanus denied that the Earth was a planet revolving around the Sun. The heliocentric world system only became an issue in Denmark in the 1660s, to a large extent facilitated by the gradual acceptance of Descartes's physics and cosmology. Erasmus Bartholin, who by the late 1640s had become personally acquainted with Descartes, subscribed to the Cartesian vortex theory and hence also to the Copernican view of the world. ${ }^{2}$ A collection of articles from 1674, De naturae mirabilibus, shows him as a supporter of the cosmological model of "Aristarch, Copernicus or Descartes". About this model or hypothesis he said that although an equally successful alternative might be imagined, the construction of such a model would be "far too arduous for mortal men" (Moesgaard, 1972, p. 136).

It has been claimed that Bartholin was not the country's first Copernican, but that the honour belongs to another Danish professor who expressed similar support sixty years earlier (Kornerup, 1943, p. 329; Danneskiold-Samsøe, 2004, p. 109). Jon Jakobsen Venusinus was a priest who in 1600 was appointed university professor in physics and three years later advanced to the chair of eloquence.

Erasmus Bartholin, who is best known for his analysis of 1669 of the double refraction of light in crystals of Icelandic spar, spent most of the time between 1646 and 1651 in Leiden. Also Longomontanus had met Descartes, who visited him in Copenhagen in 1631, mainly to discuss mathematical problems with him. On Descartes's meeting with Longomontanus and his other contacts with Danish scholars see Kragh \& Sørensen, 2007. 
From 1602 to his death in 1608 he also served as royal historiographer (Orator et Historicus Regius). Venusinus belonged to the circle of Tycho Brahe, whom he had met several times, on Hven and elsewhere (Christianson, 2000). On 13 July 1602 he gave a lecture at Copenhagen University entitled "God is a geometrician" in which he briefly referred to Copernicus. There are people, he said, who ridicule the assumption of a rotating Earth, but they are incredibly naïve in asserting that instead the starry heaven rotates. This reminded Venusinus of "Lactantius, for he could not be persuaded that the Earth is not flat [...] and ridiculed those who thought that the Earth was spherical or at least looked like a sphere." ${ }^{3}$ However, Venusinus's support of the rotating Earth did not extend to support of the more radical claim that the Earth revolved around the Sun. $\mathrm{He}$ merely repeated what Aslaksen had said a few years earlier. In any case, his lecture attracted no attention in an environment dominated by either Aristotelian or Tychonian thoughts.

\section{Frommius and the Danish academic community}

Table 1 (see the next page) lists the professors of astronomy at Copenhagen University between the establishment of the chair in 1621 and Ole Rømer's death in 1710. Longomontanus's successor was Jørgen From or Georgius Frommius, who died at the age of 46 and only served as astronomy professor for four years. The cause of his death is unknown. Although this little known professor was unoriginal as an astronomer and natural philosopher, his career and work are well suited to illuminate the state of the art in Danish astronomy in the mid-seventeenth century. Besides, he was a competent astronomer with good international relations.

Frommius (as I shall call him) was born in 1605 in Southern Jutland and received his first higher education at the Lüneburg Pædagogicum, a German Lutheran school founded in 1542. In 1625, he matriculated at the university in Helmstedt and during the next few years he also studied at the universities in Rostock, Leipzig, Wittenberg and Frankfurt an der Oder. To earn a living he went to Sorø Academy, a higher school for young noblemen established in 1623 in the Danish

3 Venusinus's lecture as excerpted in Rørdam, 1868-1877, vol. 4, pp. 523-524. For an online account of his life and work in English, see Vinilandicus, 2010, which refers to Venusinus's "revolutionary lecture on heliocentrism". According to Lactantius, a bishop who lived in the first part of the $4^{\text {th }}$ century, the belief in the sphericity of the Earth was heretical as well as ridiculous. Copernicus referred critically to him in the first book of De revolutionibus from 1543. 
city Sorø some $60 \mathrm{~km}$ southwest of Copenhagen, where he worked as a tutor or praceptor for students of the nobility. In this position he had to help the students with their studies, to act as a butler for them, and also to follow and guide them on their study tours abroad.

Table 1. Professors of astronomy (professores mathematum superiorum) at Copenhagen University, 1621-1710

\begin{tabular}{lr}
\hline Longomontanus (Christian Sørensen) [1562-1647] & $1621-1647$ \\
Georgius Frommius (Jørgen From) [1605-1651] & $1647-1651$ \\
Villum Lange [1624-1682] & $1651-1682$ \\
$\quad$ Erasmus Bartholin [1625-1698] & $1660-1676$ \\
$\quad$ Christopher Bartholin [1657-1714] & $1676-1680$ \\
$\quad$ Sebastian Lauremberg [1626-1692] & 1680 \\
Ole Rømer [1644-1710] & $1681-1710$ \\
\hline
\end{tabular}

Note: The three professors inserted between Lange and Rømer were professores vicarii substituting for Lange, the ordinary professor, during his long service as a civil servant.

Whether belonging to the nobility or not, such travels were very common and in fact indispensable for young people aspiring for an academic or perhaps a clerical position (Kragh et al., 2008, pp. 49-53; Rystad, 1983). In many cases, students would be followed by and taken care of on their travels by a preceptor, who in this way had an opportunity to pursue studies himself and obtain a higher standing in the social and academic hierarchy. Eventually he might qualify for a university position. In the period from 1541 to 1660 no less than 3,587 Danish and Norwegian students matriculated abroad, the most popular destinations being universities in Germany, the Netherlands, France and Italy (Bagge, 1984). About 87 per cent of the students were from Denmark (including 9 Icelanders) and 13 per cent from Norway. In the latter part of the period, the University of Leiden was by far the most desired destination, followed by the universities in Padua, Rostock and Franeker. These study travels would typically last for a couple of years and in some cases for as long as ten years.

From 1630 to 1635 , Frommius went on an extensive study travel with two young noblemen from Sorø Academy. He used the opportunity to matriculate at the universities in Angers and Oxford and also to visit the universities in Basel, 
Geneva, Padua, Rome and Naples. Upon his return to Denmark he matriculated at Copenhagen University, but shortly afterwards he was sent on a new journey abroad with two students of wealthy parents, this time to the Netherlands, France and England. Some of the letter correspondence from this journey is extant and provides a vivid picture of the practical, economical and scholarly aspects of study travels at the time. Having arrived in Leiden in the autumn of 1636, Frommius immediately established contacts with some of the university's famous professors. Among them were the philologists Jeremias Holtzlinus, Daniel Heinsius and Markus Boxhorn, who at the time enjoyed international recognition.

As he wrote to his patron Longomontanus, he had also met "the mathematician Jacob Golius, who for long has lived in the Orient and has brought with him many treatises by the most distinguished Arab astronomers." ${ }^{4}$ Golius, who had spent most of the 1620s in Morocco, Syria and other parts of the Arab world, was at the time professor of mathematics, astronomy and Arabic. He was responsible for the establishment in 1633 of the Leiden Observatory, the first university observatory ever. However, the observatory was equipped with traditional naked-eye instruments only. As the eminent Dutch astronomer and later director of the Leiden Observatory, Willem de Sitter, said on the occasion of the tercentenary of the observatory: "In his new observatory he now and then made observations of eclipses, comets and planets, [...] but he took no interest in the fresh marvels revealed by the new telescopes." (De Sitter, 1933, p. 325).

Nevertheless, Frommius practiced astronomy at the new observatory, reporting to Longomontanus in Copenhagen: "In Leiden we have a large Tychonic quadrant (which the Academy bought last year from the heirs of Snellius) and a sextant of just one foot. [...] We have made observations of Mercury, which agreed almost precisely with the Rudolphine tables, deviated slightly from yours and much from Lansbergen's." The Dutch instrument maker and geodesist Willebrord Snellius served as professor of mathematics and astronomy in Leiden from 1613 until his death in 1629, after which he was replaced by Golius. His large quadrant, more than two metres long and made of iron, was patterned on Tycho's instruments at Hven. Indeed, he had met Tycho in Prague and was much inspired by him (Christianson, 2000, pp. 358-361). The three astronomical tables that Frommius referred to corresponded to the three rival world systems of the time (excluding the Ptolemaic), namely, the Keplerian, the Tychonian and the Copernican.

From's correspondence, almost all of it in Latin, is deposited at the Royal Library in Copenhagen (MS Ny Kgl. Saml. 2007, $4^{\circ}$, fol. 320). The letters I quote have been translated by K. P. Moesgaard. 
In Leiden, Frommius also established contact with the Copernican astronomer Martinus Hortensius (Martin van den Hove), who was a student of Philip Lansbergen and in a Latin translation of a work by his teacher had fiercely attacked Tycho's observations and his programme of reforming astronomy. Despite their differences with regard to astronomy, Frommius seems to have admired Hortensius. "There is no one in the entire Belgia [Netherlands] I would rather meet than you," he flattered Hortensius in a letter of 1637. Later he met the Dutch Copernican in both Amsterdam and Leiden. To Longomontanus he wrote that "Hortensius now looks somewhat more gently to Tycho," adding that, "he told me that our king seriously considers building an observatory based on Tycho's principles." At the time plans were in preparation for the Round Tower observatory in Copenhagen, and Frommius naturally was keen to know more about the project (see below).

While staying in the Netherlands, Frommius looked after the printing of the new edition of Astronomia Danica that was under preparation. In January 1638 he wrote to Longomontanus: "I have, as you wished, spoken with Wilielmus [Willem Blaeu] about the printing of your Astronomia Danica; he promised to begin the work promptly, so there is no need for you to travel to Amsterdam." The new edition was published in 1640 by Joan and Cornelis Blaeu, the sons of Willem Blaeu. Having returned to Denmark in the autumn of 1638, Frommius prepared to succeed Longomontanus, then already 76 years old. He had reasons to feel confident, for in 1640 the king himself recommended him for the position when it became vacant. Shortly after having graduated as a Magister in 1641, Frommius was appointed professor of logic and two years later professor of pedagogy. These were chairs of low academic standing but typically used as stepping stones for the more attractive professorships in mathematics, medicine and theology. In 1645-1646, he was librarian at the university library and he also served as the university's notary. Frommius was now a member of the tightly connected circle of university professors and part of the country's intellectual elite. It undoubtedly helped his status and career when in 1646 he married Else Scavenius, who was related to the powerful Bartholin family.

Danish university life in the seventeenth century was dominated by a few families of which the Fincke-Bartholin family was the most influential. ${ }^{5}$ As historian

The original ancestor of the family was the mathematician and physician Thomas Fincke (1561-1656). His children included Jacob Fincke (1592-1663), who became a professor of physics, and two daughters who married Ole Worm (1588-1654) and Caspar Bartholin (1585-1629), respectively. The best known of Caspar Bartholin's sons, both of them professors, were the anatomist Thomas Bartholin (1616-1680) and the mathematician Erasmus Bartholin (1625-1698). Altogether about one half of the professors at Copenhagen University between 1620 and 1720 were members of or related to the Fincke-Bartholin dynasty. 
of science Richard Westfall wrote about the Bartholins and their dynasty: "I do not know of any other national scientific community so tightly organized around one family." (Westfall, 1994, p. 7; Kragh et al., 2008, pp. 105-109). With his marriage, Frommius became a member of the same family group that Longomontanus had entered in 1607, when he married Dorthe Bartholin, a sister of the professor of medicine Caspar Bartholin. Ole Rømer would later marry a daughter of Erasmus Bartholin. Danish university astronomy throughout the seventeenth century was thus essentially a family business.

When Longomontanus died in October 1647, Frommius finally advanced to the chair of astronomy that he had desired for long. Without distinguishing himself during his four years as a professor, he was recognized as a competent astronomer and teacher who influenced several scholars of the younger generation. Among them were Erasmus Bartholin and also the Icelander Gíslí Thorlaksson, who in 1651 wrote a dissertation in which he defended the idea, generally accepted in Copenhagen, of a rotating Earth in the centre of the universe. De stellis fixis et errantibus was not only the first printed astronomical treatise by an Icelander ever, it also included, for the first time in Denmark, a reference to Descartes's Principia philosophiae and his idea of cosmic vortices as the mechanism behind the motion of planets and comets (Moesgaard, 1972, p. 137; Gudmundsson, Kolbeins \& Vilhjalmsson, 2006). In 1652, Thorlaksson returned to Iceland to become a bishop.

Yet another student that Frommius interacted with and influenced was the Holsteinian mathematician Nicolaus Mercator, who after studies in Rostock and Leiden stayed in Copenhagen from about 1648 to 1650. He later moved to England, where he was elected a member of the Royal Society in 1666 and ten years later wrote the advanced textbook Institutionum astronomicarum that caught the attention of Isaac Newton. According to Mercator's biographer, in the period around 1650, "Mercator was in close contact with the circle of Tycho Brahe's pupils that flocked around Frommius." (Hofmann, 1950, p. 51).

Apart from a few astronomical treatises, as a professor Frommius also wrote an elementary textbook in mathematics designed for the pre-university teaching in cathedral schools and the new gymnasia that were established in the cities Odense, Roskilde, Lund and Oslo in the first part of the seventeenth century. His Arithmetica Danica covered calculations in the decimal and sexigesimal systems and their use in geodesy and astronomy. The book was published in 1649 and a new edition appeared in 1660. It seems to have been widely used, not only in Danish schools but also in Norway and may even have found its way to 
Iceland (Dahl, 2011, p. 102; Bjarnadóttir, 2006, pp. 60-62). In the eighteenth century, it was translated into Icelandic, but unfortunately the translation is no longer extant.

\section{Galilean intermezzo}

Galileo's use of the new telescope for astronomical purposes was known to Caspar Bartholin as early as in 1610, the year in which Galileo created a sensation with his Sidereus nuncius. Bartholin, who stayed in Padua in 1608-1610, was most likely acquainted with Galileo and observed the night sky himself with the optical tube. This is what he mentioned in a tract from 1617, De mundo, which was incorporated into his widely used textbook Systema physicum from 1628. But Bartholin dismissed the Copernican-Galilean world view and seems to have been unimpressed by the telescope as an astronomical instrument (Moesgaard, 1972, pp. 123-126). The first time that the telescope-"Galileo's eye"-appears in Danish language may have been in the minister and poet Anders Arrebo's Hexaëmeron rhytmico-Danicum, a work published in 1661 but written around 1635. Rendered into English, Arrebo says (Kragh et al., 2008, p. 59):

No longer must we here aspire on Milky Way to tread to gaze upon Galacti's seat with raised yet humble head;

for that Way is but stars, so small in size but great in number, and so the Milky Path we need not venture to encumber.

And if upon this truth you doubt, use Galileo's eye for thus you may yourself behold the twinkling stars on high.

Frommius was of course aware of the infamous process against Galileo which created a stir throughout learned Europe. In 1633, when Galileo was put under house arrest for life, Frommius was on his way from Padua to Paris. About five years later, when staying in Leiden, he reported the latest news about Galileo in a letter to the king's Chancellor Christen Friis:

Elzevir published recently Galileo's little book, which I dare to send to your Highness, since you asked me to keep my eyes open [...] Galileo is still alive, but his health is poor. For more than a year he has been blind in one of his eyes, and recently he has also lost the sight of the other. A mathematician from Amsterdam has been in Italy to speak with him about the determination of the longitude by means of Jupiter's moons. Galileo did 
not dare to write letters on this matter, and he is too old to travel abroad. It is inconceivable that many great men are persecuted, with the result that their most beautiful thoughts are thereby lost or remain unfinished. Consider for example Thomas Campanellus, who long ago was robbed of his right to think freely. And now Galileo is not allowed to publish his ideas in his own country. For this reason this treatise is published here without his knowledge, although in accordance with his wish, and it is distributed secretly, from one hand to another, by Elzevir junior.

Although Frommius disagreed with Galileo's cosmology, he defended his right to express his "beautiful thoughts" freely. The reference to "Campanellus" was to the Italian Dominican priest and philosopher Tommaso Campanella, who spent the years 1599-1626 in the prisons of the Inquisition. He nevertheless managed to write in 1622 an Apologia pro Galileo, in which he defended Galileo's right to argue in favour of the heliocentric universe.

In another letter from the same period, addressed to the professor of theology Jesper Brockmand, Frommius confirmed that "the Elzevirs have printed a book by Galileo on mechanics [which] I will send to you." The Leiden publishing company Elsevier, established in 1580 by Ludwig Elsevier (Lodewijk Elzevier), played a most important role in scientific and cultural circles in seventeenthcentury Europe (Davies, 1954). Since Galileo could not publish his masterwork on mechanics Discorsi intorno a due nuove scienze in Italy, the manuscript was smuggled to the Netherlands, where Elsevier published and distributed a Latin translation of it (Heilbron, 2010, pp. 329-331). The book was printed in Strasbourg and not in Leiden, as Frommius mistakenly thought.

\section{The Round Tower observatory}

Longomontanus was of course acquainted with the telescope, which he first mentioned in his Astronomia Danica from 1622. According to John Christianson (2000, p. 317), as early as on 21 June 1610 he "received a grant from the university to build a telescope with some lenses obtained by Cort Aslakssøn." This is, however, a misunderstanding. The university did grant him a small amount of money on this day, but there is no mention in the archival document of optical lenses. It merely says that Aslaksen was willing to hand over to Longomontanus some "materials" (Rørdam, 1868-1877, vol. 3, p. 367). What Longomontanus applied for and 
received money for was an unspecified speculum for use in his private residence, not a telescope. In fact, there is no documentation for the claim that he ever possessed a telescope or made use of one for astronomical observations. When he later planned the Round Tower observatory (Fig. 2), it was not meant to include a telescope either.

\section{In Theatrum astronomicum,} a tract from 1639 describing the purpose and design of the new observatory, Longomontanus included on the last page a discussion of "the instrument known as the telescope or, according to its form, the optical tube [...] invented by brilliant Belgians and excellently improved by the Italian Galileo" (Longomontanus, 1639). Although he expected the modern telescope to reveal secrets of the heavens that would surpass even those uncovered by Galileo, he was sceptical with regard to its use in astronomy: "This optical apparatus [...] has not, according to my judgment, been very important with respect to the progress in astronomy. For astronomy does not so much investigate the heavenly bodies themselves and their casual properties as [it investigates] their motions and definite periods; it hands over the peculiarities of the stars to physics, which treats them by means of optics." That is, even though Longomontanus admitted that the telescope offered some advantages, he did not consider it essential for astronomical purposes. It was of little use for positional astronomy and, moreover, would not help determine whether the Copernican or the Tychonic world system was the right one. 
Longomontanus's attitude was not particularly reactionary, for still in 1639 the telescope had little to offer to astronomers and was rarely used by them. It was not a measuring instrument but rather an instrument for discovery of celestial phenomena, and most of the telescopic discoveries had already been made by Galileo. In the words of Albert Van Helden (1974, p. 44): "During this early period the superior instruments were designed for seeing things on earth and were only occasionally turned to the heavens. This situation did not change very much until the telescope for celestial purposes parted company with the telescope designed for use on earth, a process which began slowly in Italy in the late 1630 s and spread gradually until 1645."

The traditional Galilean or "Dutch" telescopes consisted of a convex objective lens with the ocular placed between the objective and its focus, whereas the "astronomical" telescopes constructed after Kepler's design combined a convex objective and a smaller convex ocular. The latter type of instrument had the disadvantage for terrestrial purposes that it gave a reversed image, but for astronomical purposes it was far superior (Van Helden, 1974; Pannekoek, 1961, pp. 253-260). It was also expensive and not in common use in the 1640s. The first modern observatory equipped with a telescope of the astronomical type was the pioneering Paris Observatory established by the Académie Royale des Sciences in 1671 with Jean Dominique Cassini as its first director (King, 1955, pp. 58-61).

Frommius may have been the first Dane to use a telescope for astronomical observations. While in Leiden he not only observed the heavens with traditional instruments but also with a telescope, such as he reported to Longomontanus in a letter of January 1638: "Yesterday evening we observed with a telescope how the Moon covered the most western of three bright stars." He promised to continue the observations and send the results to Copenhagen. As mentioned, there was no telescope at the time at the Leiden Observatory, but Frommius does not provide any information about his telescope or from where he had obtained it. It can be safely assumed that it was of the simple Galilean type.

In Danish history of science it is generally assumed that the Round Tower observatory was equipped with a telescope in 1642, shortly after the completion of the tower, and that the telescope was provided by Frommius. The assumption or claim can be traced back to a treatise of 1784 in which the astronomer Thomas Bugge included a Historia observatorii Regii Hauniensis. Citing a tract that Frommius published in 1642, Bugge (1784, p. xx) wrote: "Upon his return from England Frommius brought with him a dioptric telescope which 
was aimed at the Copenhagen observatory and magnified objects by a factor of 100." However, as first pointed out by another Danish astronomer, Georg Ursin (1826, p. 21), Bugge quoted incorrectly from his source. What Frommius (1642, unpaginated) said in his Dissertatio astronomica, a critical work addressed to the French astronomer Jean Baptiste Morin, was this:

I have often indulged in the practice of observing objects by means of the tube and I am in the possession of a tube of such a quality that objects are magnified almost a hundred times, which provides a glimpse of all the things that were revealed to the celebrated Galileo regarding the planet Jupiter, spots on the Sun similar to those on the Moon, the various phases of Venus, and other things from current telescopic observations; nevertheless, I have not yet been able to see the things that you have noticed.

Frommius was sceptical with regard to some of Morin's observations and in general to astronomical claims based on the telescope alone. The sceptical attitude was reasonable, for at the time many astronomical phenomena allegedly seen with the telescope were false or considered unreliable. To mention but one example, around 1640 the Italian astronomer and telescope maker Francesco Fontana observed no less than nine Jupiter moons and also a moon revolving around Venus. Most leading astronomers and natural philosophers, among them Mersenne in France and Riccioli in Italy, denied that the objects observed by Fontana really existed (Kragh, 2008, pp. 7-19). While Frommius had access to and possibly possessed a telescope in 1638, there is nothing in his statement of 1642 (Fig. 3) about its origin and also there is no indication that it was intended for the new observatory in Copenhagen. He may have brought it with him either from England or the Netherlands, but in lack of evidence it remains a speculation.

Contrary to what is often claimed, in all likelihood the early Round Tower observatory was not equipped with a telescope, which only made it unexceptional. Most other observatories at the time did not possess a telescope either (Pedersen, 1976). For example, a second Dutch observatory was established in Utrecht in 1642, equipped with a sextant only, and it took until 1655 before a telescope was added. More surprising is that neither Longomontanus nor Frommius are known to have made any kind of observations from the Copenhagen observatory. On the other hand, during Frommius's period as director, two small observation buildings were added to the platform of the tower, indicating that he did make observations. If this were the case, either he did not record them or the records are no longer extant. They may have disappeared when a large part of Copenhagen burned in 1728 . 


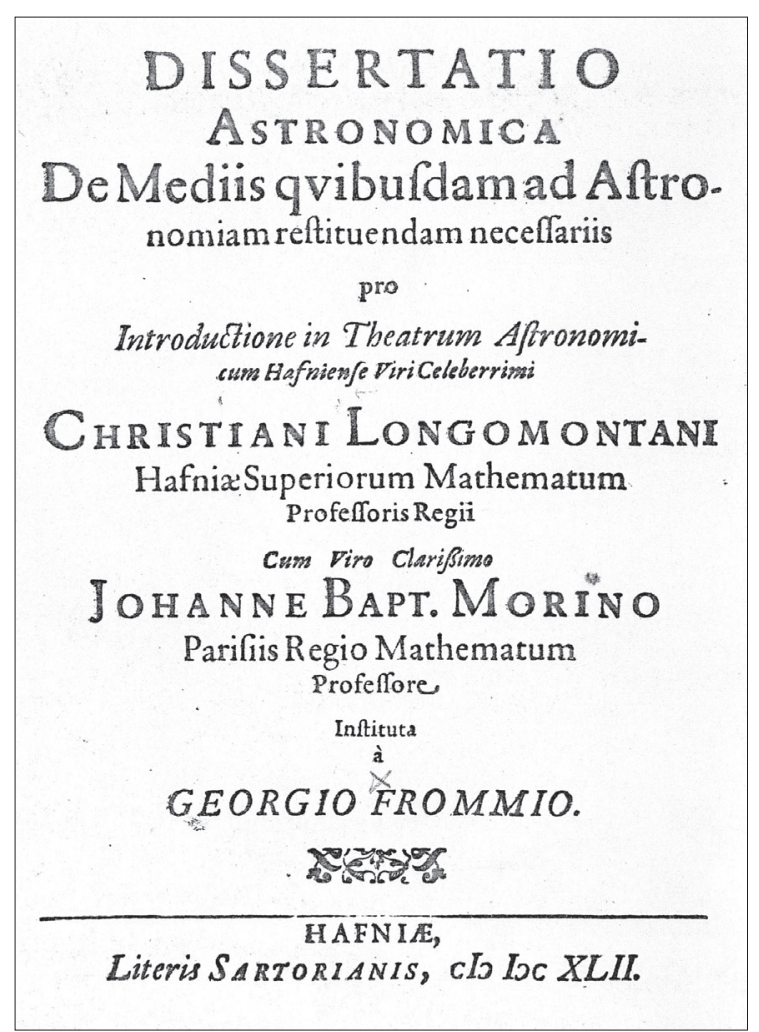

Figure 3. Frommius's treatise of 1642.
The first recorded observation from the Round Tower, of a lunar eclipse, dates from 13 March 1653, the time when Willum Lange was director. It is uncertain when a telescope was added to the observatory's instruments, but the earliest inventory from about 1650 does not mention such an instrument (Thykier, Gyldenkerne \& Darnell, 1990, pp. 469-479). Only in an inventory of 1686 does a tubus appear on the list of instruments. An observational programme was established under Erasmus Bartholin in the 1660 s, but to my knowledge there is no

evidence that it included observations with a telescope. It may well be that telescopic observations at the Round Tower became a reality only after Rømer became director in 1681 .

\section{A French-Danish literary controversy}

Two of Frommius's astronomical treatises, Dissertatio from 1642 and Responsio from 1645, were polemical works directed against Jean Baptiste Morin (Fig. 4, see the next page), a famous but also notoriously controversial professor of mathematics at Collège Royal (Hatch, 2007; Delambre, 1821, pp. 236-274). Today Morin is mostly known for his claim of having solved the problem of determining the terrestrial longitude by means of astronomical observations, such as he described in a work of 1634, Longitudinum terrestrium et caelestium nova. His 
method was based on precise measurements of the angular distance between the Moon and several fixed stars, and in this connection he introduced the innovative idea of placing a cross-wire in the common focus of the telescope's two lenses (Fouchy, 1787; McKeon, 1972). Although his method was clever, it did not work in practice, and it was generally rejected by contemporary astronomers. Nonetheless, in 1645 cardinal Mazarin procured him a pension of 2,000 livres for his efforts.

Morin was radically opposed to Copernicanism and vehemently dismissed the new natural philosophy such as promoted by, for example, Galileo, Descartes

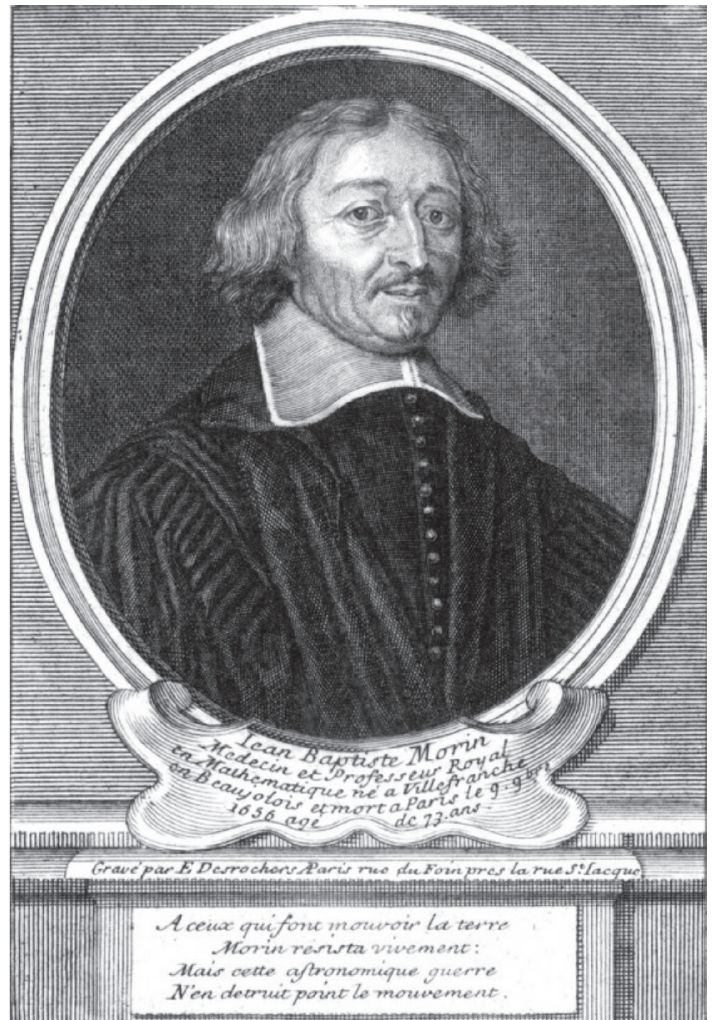

Figure 4. Jean Baptiste Morin (1583-1656).

Plate by Étienne Desrochers. and Gassendi. He attacked Lansbergen's work recommending the heliocentric theory, which caused a reply from Lansbergen's son Jacob in a book of 1633, Apologia pro commentationibus Philippi Lansbergii in motum terra. Moreover, Morin was a high-profile astrologer and convinced that astronomy could not be separated from the even more important astrology. Cosmologically he defended the Tychonian world system, which was unusual in France where Tycho's system had but few supporters. However, his version of the geocentric system included the non-Tychonian feature of planets moving in elliptical rather than circular orbits (Schofield, 1989, p. 42).

Longomontanus seems to have valued Morin as an astronomer and mathematician, and in the 1630s the two exchanged several letters. Frommius too admired Morin, whom he wished to meet during his journey in the Netherlands. Armed with a letter of recommendation from Longomontanus he planned to go to Paris to discuss Morin's theory of the longitude with him, but it is uncertain if the two 
actually met. In any case, the relationship between Morin and the two Danish astronomers soon deteriorated.

In Theatrum astronomicum, Longomontanus referred critically to Morin's treatise on the determination of the longitude and generally criticized those who did not accept Tycho's idea of a reformation of astronomy. As a result, the French astronomer published in 1641 a sharp reply in which he objected to the ideas of his colleague in Copenhagen. This was the beginning of a dispute that lasted until 1648 and was more about pride and vanity than about science. In his history of astronomy, Jean Baptiste Joseph Delambre (1821, p. 264) summarized it as follows: "It is regrettably that he [Morin] felt forced to take up the pen against an old friend, but this friend is the aggressor; and this dispute between two royal professors, one an octogenarian and the other a sexagenarian, seems to have given him the scientists' attention." The disagreement did not concern cosmology, since none of the involved astronomers were Copernicans, and neither did it concern the new Round Tower observatory, for which Morin expressed the highest praise. It was rather about minor issues such as Tycho's tables of the Moon, the accuracy of Ptolemy's ancient observations, and the reliability of Morin's telescopic measurements.

In accordance with the code of honour of the time, Morin's critique of 1641 demanded a counter-critique, which came from Frommius, Longomontanus's lieutenant, in the form of his Dissertatio astronomica. There is little doubt that it was arranged with Longomontanus or suggested by him. Delambre (1821, p. 269) referred to Frommius as Longomontanus's puppet or man of straw. The lengthy dispute involved two treatises by Frommius in support of Longomontanus (and indirectly Tycho) dating from 1642 and 1645, and three by Morin from 1641, 1644 and 1647 (see Table 2 on the next page). It ended with an anonymous tract against Frommius, printed in Paris 1648 and possibly written by Morin. Although the dispute was of little scientific substance, it was noticed in the older histories of astronomy (Bayle, 1738, p. 158; Delambre, 1821; see also Thorndike, 1958, p. 478).

Morin's suggestion of making use of Kepler's elliptical orbits was not foreign to Frommius, who briefly discussed it in his treatise of 1642 . He expressed sympathy for Kepler's programme of basing astronomy on a single system that covered all planetary motions, but refrained from supporting his solution in terms of elliptical orbits. Although not rejecting such orbits in principle, he thought they failed to reproduce the positions of the planets with sufficient accuracy. According to J. L. Russell (1964, p. 14), referring to Dissertatio astronomica, 
"George Frommius published a pamphlet in Copenhagen in 1642 in which the ellipses were strongly commended." However, this was not the case. Still around 1640 only a small minority of astronomers accepted Kepler's laws, and Frommius did not belong to that minority. Neither did Galileo, who ignored them, nor Lansbergen, who rejected them. Frommius's attitude was largely the same as Longomontanus's except that the latter, in his Astronomia Danica, had categorically dismissed the Keplerian ellipses as a betrayal of Tycho's ideas. Frommius seems to have adopted a more relaxed attitude and been more willing to consider the merits of Kepler's ellipses. All the same, he sided with his master in the belief that the geocentric system was much more natural and convincing than the heliocentric alternative.

Table 2. The Morin-Frommius controversy

Morin (1641), Coronis astronomiae jam a fundamentis ... restituae; qua respondetur ad introductionem in Theatrum Astronomicum ... Christiani Longomontani (Paris).

Frommius (1642), Dissertatio astronomica de mediis ... Christiani Longomontani ... cum ... Johanne Baptista Morino instituta (Copenhagen).

Morin (1644), Defensio astronomiae a fundamentis integre et exacte restitutae: Contra ... Georgii Frommii dani dissertationem astronomicam (Paris).

Frommius (1645), Georgii Frommii responsio ad ... Johannis Baptistae Morini defensionem astronomiae restitutae (Copenhagen).

Morin (1647), La Science des Longitudes... (Paris).

Anonymous (1648), Epistola castigatoria adversus G. Frommium ... circa fundamentalem astronomiae restitutionem, Morino inscripta (Paris).

\section{Commemorating Tycho}

On 6 October 1647, the learned Frenchman Isaac Lapeyrère wrote a letter to the Danish polymath and natural philosopher Ole Worm, professor of medicine at Copenhagen University. He told him about Pierre Gassendi (Fig. 5)—“an excellent man who values you highly and whose reputation I believe you are well aware of" - that he "has got the idea and wish to write the life of your famous 
Tycho Brahe" (Worm, 1968, p. 280; Kragh, 2007). Although Worm himself had not known Tycho, he responded enthusiastically to Lapeyrère's request of supplying Gassendi with information and sources concerning the astronomer's life. Longomontanus had unfortunately passed away only a few days ago, he wrote, but "his successor Frommius, with whom I have discussed Tycho, says that he has his unpublished manuscripts to the work against the Scotsman Craig and also some private letters concerning his travels and departure

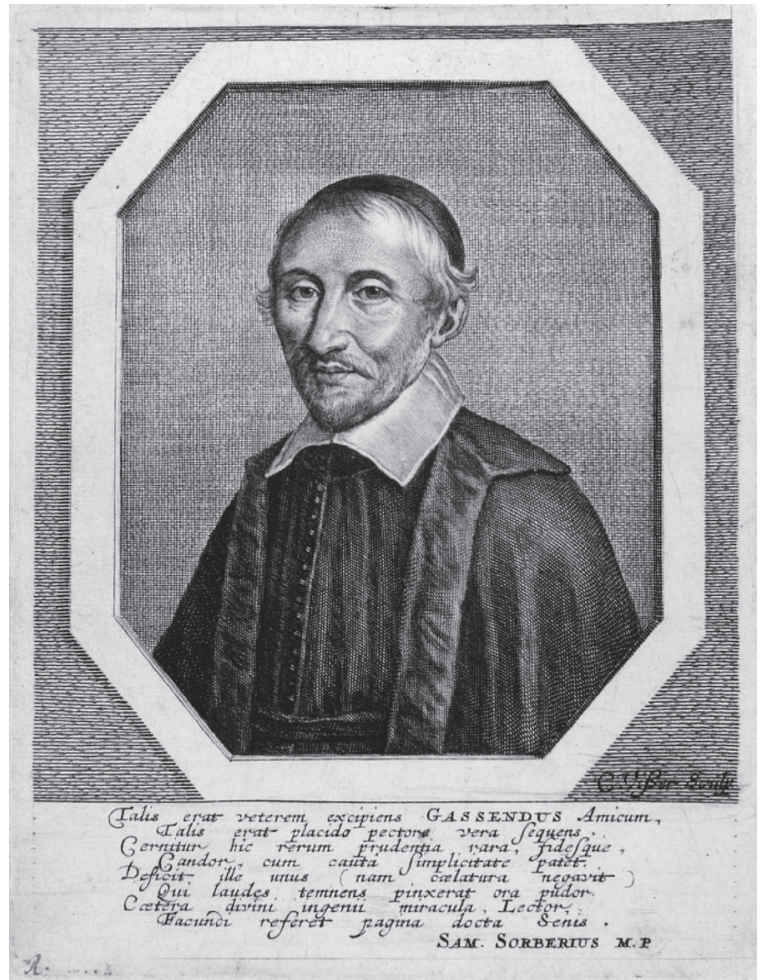

Figure 5. Pierre Gassendi (1592-1655).

Plate by Cornelis Visscher. from Denmark." (Worm, 1968, p. 284). In April 1648, Lapeyrére told Worm that Gassendi was most grateful and that he had sent a copy of "his astronomical textbook to your celebrated Frommius," a reference to Gassendi's important Institutio astronomica, published in 1647 . Having thus been properly introduced to Gassendi, Worm addressed him directly (Worm, 1968, p. 317; Gassendi, 1658, p. 518):

I have considered the matter with my friends, in particular with our mathematician Frommius. I know that he has in his possession several things and that he keeps the Scotsman Craig's tract against Tycho and also his [Tycho's] defence, which he has decided to publish as a whole; moreover, he recently gave a beautiful talk about Tycho's life at a public festivity; [...] in his wish to win your friendship and favour he has promised to inform you by letter about the matter; he will undoubtedly provide you with things that were lacking in my report. 
As demonstrated by a letter from Frommius to Gassendi of 9 June 1648, the two were in contact, but it is unclear what kind of information Frommius passed on to Paris (Gassendi, 1658, p. 518).

The reference in the letters and also in Gassendi's final biography to "the Scotsman Craig" may need some explication, which in brief is as follows. Tycho had in 1588 sent a copy of his book on comets, De mundi aetherei, to the Scottish mathematician and physician John Craig, who as an Aristotelian responded with a sharp criticism of Tycho's conclusion regarding the large comet and its distance from the Earth (Mosley, 2002). Tycho consequently decided to write and publish a detailed defence — an apology—in which he refuted Craig's arguments. $\mathrm{He}$ most likely dictated a manuscript to Longomontanus around 1590 or perhaps Longomontanus wrote it himself following Tycho's instructions. Indeed, this is what Frommius wrote in his Dissertatio of 1642, where he reproduced parts of the apology and stated that he wanted to publish it. However, no published version of Tycho's anti-Craig tract is known from the time. Frommius seems to have been seriously interested in Gassendi's Tycho project and it may have been in this context that he visited Hven to see whatever was left of the former glory of Uraniborg and its surroundings. Among the things he found was a stone with an inscription that marked the completion of Tycho's paper mill in 1592 and of which he made a copy (Gram, 1745, p. 265). The stone is now placed at Tycho's birthplace Knudstrup in southern Sweden.

Neither Frommius nor Worm saw the fruits of Gassendi's and their own efforts to produce a biography in honour of the famous Tycho. Tychonis Brahei vita, the first full biography of a scientist ever, appeared in Paris in 1654 and already the next year a new edition was published in the Hague. ${ }^{6}$ Gassendi sent four copies to King Frederik III in Copenhagen, from where the Chancellor could tell him that his Majesty was pleased with the book (Gassendi, 1658, p. 538).

Only in 1951 was the book translated into another language than Latin, namely Swedish, and it took until 1996 before a French translation appeared. There is no English translation. See Kragh, 2007. 


\section{Conclusions}

Georgius Frommius made his way to the academic establishment by acting as a butler, coach and teacher for young students on their travels abroad, a career pattern which was not unusual in the seventeenth century. As illustrated by his letters from Leiden and elsewhere in the period 1636-1638, he used his time abroad for studies in mathematics and astronomy, including observations with a telescope. He probably brought a telescope with him to Copenhagen, but contrary to what is generally assumed the instrument was not used at the Round Tower observatory. His letters from Leiden also referred to Galileo and the publication of his book on mechanics, which he sent to his patrons in Copenhagen. A few years after having returned to Denmark he became engaged, as a kind of substitute for Longomontanus, in a dispute with Jean Morin in France. In connection with this dispute he wrote two treatises on the proper methods of astronomy, in both of them dealing with the role of the telescope.

Although subscribing to the Tychonic world system, Frommius accepted, as Longomontanus had done, the daily rotation of the Earth and also considered the possibility of Keplerian planetary orbits. After the death of Longomontanus in 1647 he assisted Ole Worm in supplying information about Tycho Brahe's life and research. There are no known records of observations made by Frommius from the Copenhagen observatory with either telescopes or traditional instruments, but it is likely that he did observe with the latter kind of instruments. Regular observations with a telescope seem to have started only after Rømer became director in 1681.

\section{Acknowledgments}

I am grateful to Kristian P. Moesgaard, Fritz S. Pedersen and Brian Hepburn for help relating to the Latin texts. 


\section{References}

Bagge, S. (1984), 'Nordic students at foreign universities until 1660,' Scandinavian Journal of History, vol. 9, pp. 1-29. http://dx.doi.org/10.1080/03468758408579030

Bayle, P. (1738), A General Dictionary: Historical and Critical, vol. 7, London: James Bettenham.

Bjarnadóttir, K. (2006), Mathematical Education in Iceland in Historical Context, PHD thesis, Roskilde University.

Blair, A. (2000), 'Mosaic physics and the search for a pious natural philosophy in the late renaissance,' Isis, vol. 91, pp. 32-58. http://dx.doi.org/10.1086/384625

Bugge, T. (1784), Observationes Astronomicae Annis 1781, 1782 \& 1783, Copenhagen: Nicolai Møller.

Christianson, J. R. (2000), On Tycho's Island: Tycho Brahe and His Assistants 1570-1601, Cambridge: Cambridge University Press.

Dahl, G. (2011), Books in Early Modern Norway, Leiden: Brill. http://dx.doi.org/10.1163/ej.9789004207202.i-242

Danneskiold-Samsøe, J. (2004), Muses and Patrons: Cultures of Natural Philosophy in Seventeenth-Century Scandinavia, Lund: Ugglan.

Davies, D. W. (1954), The World of the Elseviers, 1580-1712, The Hague: Martinus Nijhoff. http://dx.doi.org/10.1007/978-94-015-1061-5

Delambre, J. B. J. (1821), Histoire de l'Astronomie Moderne, vol. 2, Paris: Libraire pour les Sciences [New York: Johnson Reprint Corporation, 1969].

De Sitter, W. (1933), 'Tercentenary of the Leiden Observatory', The Observatory, vol. 56, pp. 323-328.

Fouchy, J.-P. (1787), 'Sur la date de l'application des lunettes aux instruments, ... et sur l'auteur de ces decouvertes,' Mémoire de l'Académie Royale des Sciences pour l'Anné 1783, pp. 385-392.

Frommius, G. (1642), Dissertatio astronomica de mediis ... Christiani Longomontani ... cum ... Johanne Baptista Morino instituta, Copenhagen.

Gassendi, P. (1658), Opera Omnia: in sex tomos divisa, vol. 6, Leiden.

Gram, H. (1745), 'Videre fortsettelse af rare og mest utrykte Efterretninger om Tyge Brahe,' Danske Magazin, vol. 1, pp. 258-289.

Gudmundsson, E.; Kolbeins, E. \& Vilhjálmsson, T. (2006), 'Copernicanism in Iceland,' Organon, vol. 35, pp. 83-101.

Hatch, R. A. (2007), 'Morin, Jean-Baptiste,' in T. Hockey (ed.) Biographical Encyclopedia of Astronomers, New York: Springer, pp. 806-807.

Heilbron, J. L. (2010), Galileo, Oxford: Oxford University Press. 
Hofmann, J. S. (1950), Nicolaus Mercator (Kauffman), sein Leben und Wirken, vorzugsweise als Mathematiker, Wiesbaden: Verlag der Akademie der Wissenschaft und der Litteratur in Mainz.

King, H. C. (1955), The History of the Telescope, London: Griffin \& Company.

Kornerup, B. (1943), 'Venusinus, Jon Jakobsen,' in P. Engelstoft (ed.) Dansk Biografisk Leksikon, vol. 25, Copenhagen: Schultz, pp. 327-329.

Kragh, H. (2007), 'Received Wisdom in Biography: Tycho Biographies from Gassendi to Christianson,' in T. Söderqvist (ed.) The History and Poetics of Scientific Biography, Aldershot: Ashgate, pp. 121-134.

— (2008), The Moon That Wasn't: The Saga of Venus'Spurious Satellite, Basel: Birkhäuser.

Kragh, H. \& Sørensen, H. K. (2007), 'An odd couple: Descartes and Longomontanus. A contribution to Cartesianism in seventeenth-century Denmark,' Ideas in History, vol. 2, pp. 9-36.

Kragh, H.; Nielsen, H.; Nielsen, K. H. \& Kjærgaard, P. C., eds. (2008), Science in Denmark: A Thousand-Year History, Aarhus: Aarhus University Press.

Longomontanus (1639), Introductio in theatrum astronomicum, Copenhagen.

McKeon, R. (1972), 'Les débuts de l'astronomie de precision,' Physis, vol. 14, pp. 221-242.

Moesgaard, K. P. (1972), 'How Copernicanism took root in Denmark and Norway,' Studia Copernicana, vol. 5, pp. 117-152.

(1977), 'Cosmology in the Wake of Tycho Brahe's Astronomy' in W. Yourgrau \& A. D. Beck (eds.) Cosmology, History, and Theology, New York: Plenum Press, pp. 293-305. http://dx.doi.org/10.1007/978-1-4615-8780-4_19

Mosley, A. (2002), 'Tycho Brahe and John Craig: The Dynamic of a Dispute,' in J. R. Christianson et al. (eds.) Tycho Brahe and Prague: Crossroads of European Science, Frankfurt am Main: Harri Deutsch, pp. 70-83.

Pannekoek, A. (1961), A History of Astronomy, New York: Dover Publications.

Pedersen, O. (1976), 'Some early European observatories,' Vistas in Astronomy, vol. 20, pp. 17-28. http://dx.doi.org/10.1016/0083-6656(76)90006-4

Rørdam, H. F. (1868-1877), Kjøbenhavns Universitets Historie fra 1537 til 1621, vols. 1-4, Copenhagen: Den Danske Historiske Forening.

Russell, J. L. (1964), 'Kepler's laws of planetary motion, 1609-1666,' British Journal for the History of Science, vol. 2, pp. 1-24. http://dx.doi.org/10.1017/ S0007087400001813

Rystad, G., ed. (1983), Europe and Scandinavia: The Process of European Integration in the $17^{\text {th }}$ Century, Lund: Scandinavian University Books.

Schofield, C. (1989), 'The Tychonic and Semi-Tychonic World Systems,' in R. Taton \& C. Wilson (eds.) Planetary Astronomy from the Renaissance to the Rise of Astrophysics, Cambridge: Cambridge University Press, pp. 33-45. 
Thorndike, L. (1958), A History of Magic and Experimental Science, vol. 8, New York: Columbia University Press.

Thykier, C.; Gyldenkerne, K. \& Darnell, C. (1990), Dansk Astronomi Gennem Firehundrede Aar, vols. 1-3, Copenhagen: Rhodos.

Ursin, G. F. (1826), Historisk Beretning om Universitets-Observatoriet paa Rundetaarn, Copenhagen: Thieles Bogtrykkerie.

Van Helden, A. (1974), 'The telescope in the seventeenth century,' Isis, vol. 65, pp. 38-58. http://dx.doi.org/10.1086/351216

Vinilandicus (2010), 'Jon Jakobsen Venusinus.' [Website] Retrieved from http//vinilandicus.dk/WhoisJonJakobsen.html [accessed 19 Feb 2015]

Voelkel, J. R. (2000), 'Severin, Christian,' in W. Applebaum (ed.) Encyclopedia of the Scientific Revolution, New York: Garland Publishing, pp. 597-598.

Worm, O. (1968), Breve fra og til Ole Worm, vol. 3, transl. by H. D. Schepelern, Copenhagen: Munksgaard.

Helge Kragh graduated from the University of Copenhagen (physics) in 1970. As professor of history of science and technology at Aarhus University, he has taught courses in history and philosophy of science. His research is mainly focused on the history of post-1850 physical, astronomical and chemical sciences. 